\title{
Homicide in children under ten years old in México: A 20-year study
}

\section{Homicidio en menores de 10 años en México: 20 años de estudio}

\author{
Jorge Martin Rodríguez ${ }^{1}$ Julio Cesar Campuzano² (D) Yamileth Ortiz Gómez ${ }^{3}$ \\ yortizg@gmail.com \\ 1 Pontificia Universidad Javeriana, Institute of Public Health, Bogota, Colombia. , 2 National Institute of \\ Public Health, Population Health Research Center, Cuernavaca, Mexico. 3 National Institute of Public \\ Health, Cuernavaca, Mexico.,
}

OPEN ACCESS

Citation: .Rodríguez JM, Campuzano $\mathrm{JC}$, Ortíz GY. Homicide in children under ten years old in México: A 20-year study. Colomb Méd (Cali), 2021; 52(3):e2024492 http://doi. org/10.25100/cm.v52i 3.4492

Received : 07 Sep 2020

Revised: 28 Apr 2021

Accepted : 01 May 2021

Published: 17 Jun 2021

Keywords:

Homicide, child abuse, intentional injuries, violence, social justice, death certificates, public policy, Mexico

Palabras clave:

Homicidios, maltrato infantil, lesiones intencionales, violencia, justicia social, certificados de defunción, política pública, México

Copyright: (c) 2021 Universidad del Valle

(c) (6) $\odot$
Availability of the data: All information was extracted from databases and mortality records validated by the General Directorate of Epidemiology of the Mexican Ministry of Health and can be requested from the corresponding author, if required.

Contributions: JMR and JCC conceived the study. JCC, JMR, and YO participated in the analysis of the information, the writing of the manuscript and the approval of the final version of the entire document.

\section{Abstract}

\section{Background:}

In a society, children are the most vulnerable members of the population. Violence experienced in Mexico during the last decade has also affected children under ten years of age.

\section{Objetive:}

Analyze the trend of homicides in children under ten years from 1998 to 2017.

\section{Methods:}

A longitudinal study of homicides in children under ten years of age was conducted in Mexico from 1998 to 2017. Several analytic techniques were applied to study the mortality tendency during the study period in this population.

\section{Results:}

5,188 homicides occurred in children under ten years during the study period, $57 \%$ were in boys and $70 \%$ were in children under five years of age. Hanging and strangulation were the most common types of homicides for girls under one year of age. The home was the most frequently reported place of occurrence. Children between 5-10 years old were 3.1 times more likely to die from a firearm injury than those under 0-5 years old. It was also found that minors who resided in the Northern region of the country had a 2.7 times higher risk of firearm mortality compared to those who resided in the central region.

\section{Conclusions:}

It is important to implement protective measures, especially for those under one year, along with the need to create multi sectorial interventions that ensure protective environments for children. Moreover, observatory programs could be used to improve the quality of administrative records for decision-making. 


\section{Conflicts of interest:}

All authors declare that we have no conflicts of interest with this publication.

\section{Acknowledgments:}

The authors want to thank to Dra Martha Hijar, MSc Anaid Hernández Alvarez and MSc Dzoara Santoyo Castillo for her comments and support in the review of the article.

\section{Corresponding author:}

Yamileth Ortiz Gómez. Cra 45 No. 4571 Interior 2, Apto 302. Bogotá. E-mail: yortizg@gmail.com

\section{Resumen}

\section{Antecedentes:}

En una sociedad, los niños son los miembros más vulnerables de la población. La violencia vivida en México durante la última década también ha afectado a personas menores de 10 años.

\section{Objetivo:}

Analizar la tendencia de los homicidios en niños menores de 10 años de 1998 a 2017.

\section{Métodos:}

Se realizó un estudio longitudinal de homicidios en niños menores de 10 años en México de 1998 a 2017. Se aplicaron diversas técnicas analíticas para estudiar la tendencia de la mortalidad durante el período de estudio.

\section{Resultados:}

De los 5,188 homicidios ocurridos, el $57 \%$ fueron en niños y el $70 \%$ en menores de cinco años; el ahorcamiento y el estrangulamiento fueron los principales mecanismos de homicidio de niñas menores de 1 año. El hogar fue el lugar de mayor ocurrencia de homicidios. Los niños entre 5 y 10 años murieron 3.1 veces más por arma de fuego que los menores de 0 a 4 años. Los menores que residían en el norte del país tenían 2.7 veces más riesgo de mortalidad por armas de fuego en comparación con los que residían en la región central.

\section{Conclusiones:}

Es importante implementar medidas de protección, especialmente para los menores de un año, junto con la necesidad de crear intervenciones multisectoriales que aseguren ambientes de protección para los niños. Además, los observatorios podrían utilizarse como una estrategia para mejorar la calidad de los registros administrativos y focalizar la toma de decisiones.

\section{Remark}

\section{1) Why was this study conducted?}

This is an article derived from the interes of Mexican Academics with respect to the deaths in some vulnerables groups such as women, elderly people and children, as in this case.

\section{2) What were the most relevant results of the study?}

The force excess was associated with children violence and death in less than five years old, and firearms in children between 5 to 10 years old were used. The household was the place more associated with those events. Children that lived in northern areas had three times more died risk with respect to those that lived in central areas of the country associated with firearms used.

\section{3) What do these results contribute?}

It is necessary to design and implement multi-sectoral interventions that can support protection for children. Surveillance systems could be used as a strategy to improve the quality of administer registers and to help decision-makers. Furthermore, we believe that these issues need to be followed in future studies that could identify the possible correlation among homicides in children, hospitalization due to intentional injuries and complaints of physical abuse in this population. 


\section{Introduction}

Deaths by homicide of children in Mexico has not received particular attention in the country's public policies despite the fact that the Convention on the Rights of the Child ${ }^{1}$, which was unanimously approved by the General Assembly of the United Nations in 1989 and ratified by Mexico in 1990, establishes in Article 19 the right of all boys, girls and adolescents to a life free of violence and binds the signatory states to adopt the appropriate legislative, administrative, social and educational measures to protect children against violence. This institutional omission is particularly problematic in a national context such as that of Mexico, where violent deaths have increased dramatically from 2007 to date in the context of the war against drug trafficking ${ }^{2}$.

In recent decades, programs related to child survival in Mexico have been geared towards diseases that are preventable by vaccination and nutritional deficiencies. As a result of campaigns such as breastfeeding promotion, growth monitoring, immunization and oral rehydration therapy, millions of lives have been saved, and the quality of life of many boys and girls has been improved $^{3}$. However, the World Report on Child Injury Prevention of the World Health Organization (WHO $)^{4}$ draws attention to injuries as the leading cause of death and disability among children worldwide. This report emphasizes the need to address this problem as a central part of all initiatives that are carried out to reduce damage to child health and improve overall well-being.

Therefore, it is necessary to establish differences between injuries referred to as unintentional and intentional according to the mechanism that causes them. Unintentional injuries include those produced by burns, falls, poisoning, etc. Intentional injuries produced by another person or by the injured person include homicides and suicides ${ }^{5}$. Although it may seem easy to make this distinction, in practice, it is difficult, especially in children under five years of age and especially those under two years of age, due to the close relationship children have with those who use violence against them. It is known that such deaths are registered precisely because of the legal implications involved ${ }^{6}$. While homicide is the most visible effect of violence, it should be emphasized that deaths only represent a fraction of the total burden of violence ${ }^{6,7}$; for each death, an indeterminate number of violent events occur that lead to injuries or other health effects - including both physical and mental sequelae and disabilities - some of which, for various reasons, are never recorded by state institutions ${ }^{8}$.

The classification of violence proposed by the WHO attempts to characterize the different types of violence and relate them to the bonds between the aggressor and the victim ${ }^{5}$. In this study, reference is made to interpersonal violence between people who are well known to one another and that usually occurs in the home. In addition to the recommendations of the World Report on Violence and Health for intervening in the problem, the INSPIRE handbook, an initiative of several international and non-governmental organizations, establishes a series of recommendations with proven evidence to mitigate and end violence against children; among these recommendation are education and changes in attitudes towards life, response and support from institutions responsible for access to justice, and the establishment of norms and values in the face of situations of violence ${ }^{9}$. The objective of this article is to characterize homicide deaths for children under ten years of age in Mexico through the analysis of official records of homicide deaths from 1998-2017, focusing the public attention on a problem that is one of the most severely neglected social issues in Mexican society.

\section{Materials and Methods}

\section{Design and population}

A longitudinal design was used to describe and analyze the deaths recorded as homicides in children 0-10 years of age in the Mexican Republic over a period of 20 years, from 1998 to 2017. The analyzed information included the variables recorded on the death certificates: age, sex, year, place of occurrence of the event and weapon used/mechanism. The information was 
extracted from mortality databases and records validated by the General Directorate of Epidemiology of the Mexican Ministry of Health.

The deaths with External Causes of Injuries and Poisons, categorized by codes Y00 to Y09 and X85 to X99, according to the tenth revision of the International Classification of Diseases (ICD $\mathrm{X}$ ), were analyzed ${ }^{10}$. For this analysis, the causes were grouped as follows:

- Blows without weapons, rape (Y04 to Y05),

- Attack with corrosive substances and chemical products (X85 to X89),

- Poisoning (X90),

- Hanging, strangulation, suffocation (X91),

- Drowning (X92),

- Attack with a firearm and explosives (X93 to X98),

- Attack with sharp or pointed object (X99 to Y00),

- Negligence, abandonment and abuse (Y06 to Y07) and

- Other means and those not specified (Y01 to Y03, Y08 to Y09, Y35, Y36).

\section{Processing and analysis of information}

Based on the recommendation of experts in the analysis of mortality by injuries ${ }^{11,12}$, corrections and adjustments were made to the cases with homicide mechanisms in the so-called nonspecific codes (Y33-Y34) or garbage codes (R codes). Three adjustments were made to the data:

First adjustment: The nonspecific codes or garbage codes of Chapter XVIII, which in the CIE X Revision are defined within-group " $\mathrm{R}$ ", were added proportionally to the homicide mechanism of death by intentionally externally caused injuries (homicides).

Second adjustment: The injury codes that ignored whether the injury was accidentally or intentionally inflicted, Y33 and Y34, were added proportionally to the product of the previous correction.

Third adjustment: An imputation process (information assignment) was performed for cases with missing data, as age or sex. This imputation was made in the following way: if there were thirty lost data items for sex, the distribution of this variable for each age was taken, and these data were distributed proportionally between children according to the sex distribution.

\section{Statistical analysis}

The variables analyzed were age, sex, year of occurrence of death, place of occurrence of the event and homicide type (by the weapon used/mechanism causing the death). In the analysis of mortality, the absolute values represented by the annual number of cases and their relative distribution at the percentage level were taken into account. A trend analysis of total deaths was performed by age group, sex and year of occurrence for the study period. Specific rates were generated per hundred thousand inhabitants based the reports of basic health indicators in the Americas established by the Pan American Health Organization ${ }^{13}$. For the denominators, the population projections reported by CONAPO (2009) were used for each of the years analyzed.

A multiple linear regression model was performed using homicide rate as dependent variable, and sex and years as independent variables to assess mortality trends. An analysis of deaths in children under 5 years of age was performed to more precisely identify what occurred in this group based on the type of homicide (weapon used/mechanism), by age and sex.

Additionally, a multiple logistic regression model was made in order to determine the type of homicides that were more common across regions, with the type of homicide as the dependent variable coded as " 1 " if it was firearm homicide; and " 0 " if otherwise (other means/undetermined). The 


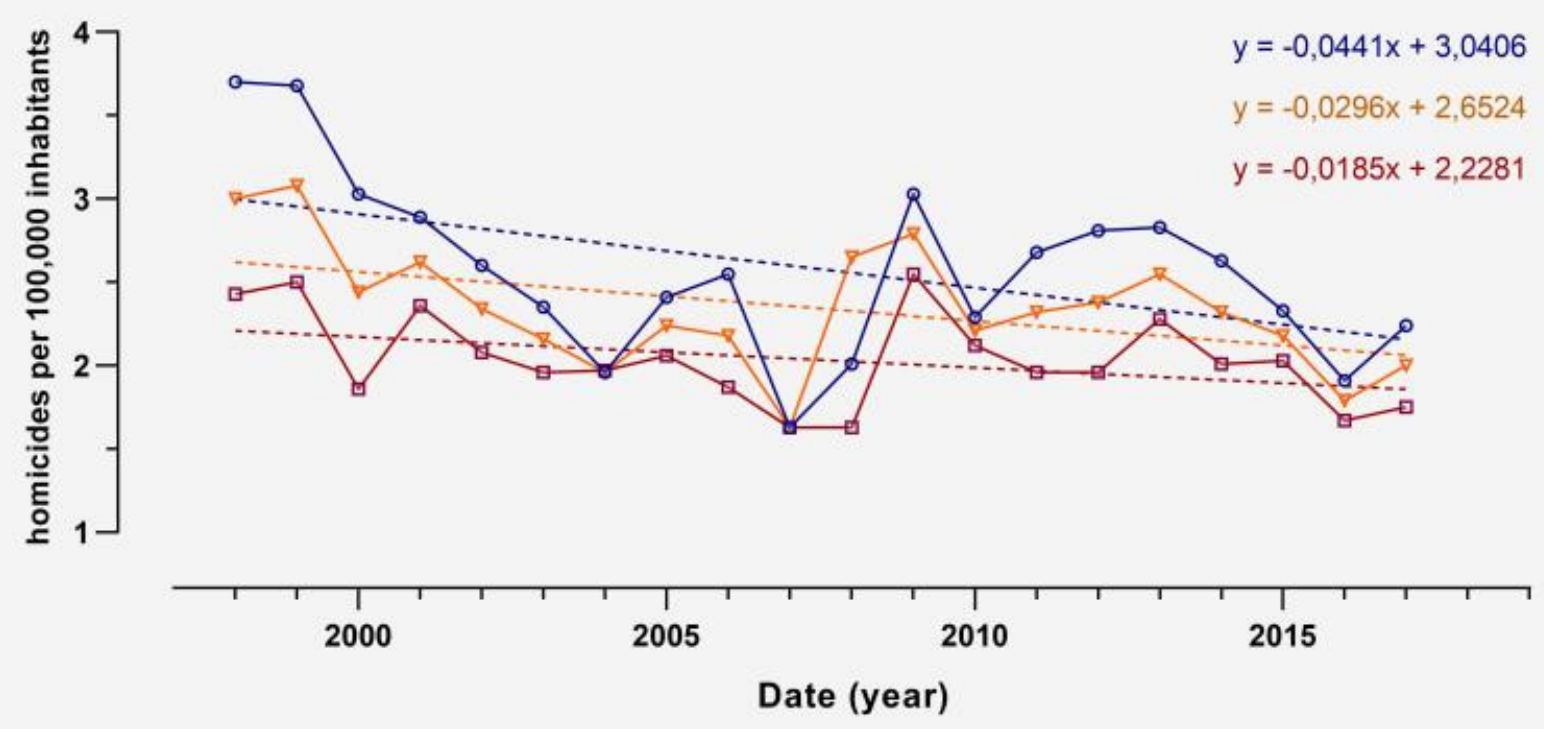

$\rightarrow$ Boys $\rightarrow$ Girls $\rightarrow$ Children

Figure 1. Homicide mortality rates among children 0-10 years old, in Mexico. 1998-2017 Source: Prepared from the databases of the National Health Information System (SINAIS, 1998-2017)

regions were coded as follows: Center (0), North (1), West (2), East (3) and South (4). Models were also adjusted by sex (girls (0), boys (1)), and age categories (0-5 years (0), 5-10 years (1)).

$P$ values and $95 \%$ confidence intervals were calculated and presented for all coefficients derived from models. All analyses were carried out using Stata, version $13.0^{14}$.

\section{Results}

A total of 5,188 deaths were recorded as homicides in children ages 0 to 10 years from 19982017 in Mexico. Each year, 259 children under ten years of age died from homicide; 56.7\% were boys. Among all these deaths, $70.1 \%$ were of children younger than five years. The girl/ boy ratio was 1:1.31.

Figure 1 shows that during the 20 years of the study, there was a decreasing trend in mortality for boys and girls, although the decrease for boys was almost double, compared to the decrease observed for girls. This figure also shows that rates were consistently higher (between $10 \%$ and 30\%) for boys than girls during the study period. By 1998 and 2003, the risk of dying from a homicide was as much as 60\% higher for boys than for girls, but between 2004 and 2007, mortality rates were similar by sex. Although the trend was irregular until 2017, it tended to decrease over the years.

When the linear regression for the study period was applied, it was found that boys had a mortality rate from homicides of 0.54 (95\% CI: $0.30-0.79)$ higher compared to girls $(p<0.001)$. Additionally, due to the one-year increase, mortality was reduced by 0.03 , meaning that this decrease was statistically significant $(p<0.01)$ (Data not shown).

The analyzes of homicides by weapon use/mechanism and by age group show that $70.1 \%$ of homicides occurred in children 0 to 4 years of age (Table 1); in this group, homicides by "other means and/or undetermined" accounted for $42.6 \%$ of homicides, and $29 \%$ of homicides in children ages 5 to 10. In this same age group, homicides in which a gun or a knife was used 
Figure 1. Distribution of the mechanisms for homicide according to age group and sex, Mexico (1998-2017)

\begin{tabular}{|c|c|c|c|c|c|c|c|}
\hline \multirow{2}{*}{$\begin{array}{l}\text { Homicide by type of weapon used/ } \\
\text { mechanisms / age group - sex }\end{array}$} & \multicolumn{2}{|c|}{0 to 5 years } & \multicolumn{2}{|c|}{5 to 10 years } & \multicolumn{2}{|c|}{ Subtotals by sex } & \multirow{2}{*}{ Total n (\%) } \\
\hline & Boys n $(\%)$ & Girls n (\%) & Boys n (\%) & Girls n (\%) & Boys n (\%) & Girls n $(\%)$ & \\
\hline Other means & $867(42.9)$ & $684(42.3)$ & $278(30.1)$ & $166(26.5)$ & $1145(38.9)$ & $852(37.9)$ & $1197(38.5)$ \\
\hline Firearm & $325(16.1)$ & $199(12.3)$ & $339(36.8)$ & $206(32.9)$ & $665(22.6)$ & $404(18.0)$ & $1069(20.6)$ \\
\hline Hanging and strangulation & $260(12.9)$ & $236(14.6)$ & $112(12.1)$ & $110(17.5)$ & $374(12.7)$ & $347(15.4)$ & 721 (13.9) \\
\hline Physical abuse & $195(9.6)$ & $183(11.3)$ & $22(2.4)$ & $10(1.6)$ & $215(7.3)$ & $193(8.6)$ & $410(7.9)$ \\
\hline Sharp instrument & $121(6.0)$ & $108(6.7)$ & $86(9.3)$ & $79(12.6)$ & $209(7.1)$ & $189(8.4)$ & $394(7.6)$ \\
\hline Drowning & $170(8.4)$ & $120(7.4)$ & $56(6.1)$ & $30(4.8)$ & $224(7.6)$ & $148(6.6)$ & $374(7.2)$ \\
\hline Beating, altercation, rape & $52(2.6)$ & $60(3.7)$ & $7(0.8)$ & $12(1.9)$ & $59(2.0)$ & $72(3.2)$ & $130(2.5)$ \\
\hline Corrosive substance & $14(0.7)$ & $23(1.4)$ & $15(1.6)$ & $9(1.4)$ & $29(1.0)$ & $31(1.4)$ & $62(1.2)$ \\
\hline Poisoning & $14(0.7)$ & $5(0.3)$ & $8(0.9)$ & $5(0.8)$ & $24(0.8)$ & $9(0.4)$ & $31(0.6)$ \\
\hline Total & $2019(100)$ & $1618(100)$ & $924(100)$ & $627(100)$ & $2943(100)$ & $2245(100)$ & $5188(100)$ \\
\hline
\end{tabular}

Source: Prepared from the databases of the National Health Information System (Sistema Nacional de Información en Salud - SINAIS, 1998-2017).

were the most common ones (46\%). Physical force (e.g., beating, hanging, strangulation, drowning and physical abuse) was reported in approximately $23 \%$ of cases.

Among children under nine years of age, homicides caused by firearms (20.6\%) and by hanging or strangulation (13.9\%) were the most prevalent, while poisoning was the least reported type $(0.6 \%)$. The results show that compared to boys, girls were more likely to die from physical abuse, beating, hanging (33.8\%). 56.7\% of victims ages 0 to 10 were boys. Given that $70 \%$ of deaths occurred in children under 5 years of age and that sex differences were observed, the following results stratified by age and sex are presented:

\section{Patterns on girls under 5}

Approximately $40 \%$ of all homicides of children occurred under one year of age, as shown in Tables 2 and 3. In children, less than 5 years, the numbers for hanging and strangulation were 14.6 for girls and 12.9 for boys. Among girls one year of age, the most common type of homicide was drowning, and after two years, it was firearm homicide. The number of homicides recorded under the nonspecific mechanisms "other means" appears to decrease by age (Table 2).

\section{Patterns on boys under 5}

For boys, those under one year of age accounted for $40 \%$ of the mechanism for death and presented a similar pattern for girls. In children under one year of age, the most frequent mechanisms of homicide death were hanging and strangulation, while among those older than one year, firearms were the most common mechanism. Misclassified mechanisms ranged between $35 \%$ and $48 \%$ at different ages (Table 2).

One-third of the events occurred at home. Public thoroughfares ranked second. A striking feature was the high percentage of child deaths for which the site of occurrence was not registered, 25\%. When comparing the place of occurrence by sex, significant differences were found in homicides that occurred at home, where the number of deaths was higher in girls $(p<0.005)$. For homicides that occurred at public places, such as streets or highways, there were no differences by gender (data not shown).

On the other hand, for the period of study, boys had a 31\% higher risk of death than girls by firearms. Those between 5-10 years old died 3.1 times more by a firearm than those under 0-4 years old. It was also found that minors who resided in the North of the country (states of Tamaulipas, Chihuahua, Nuevo León, Durango, Coahuila, Baja California Norte y Sur, and Sonora) had 2.7 times higher risk of mortality by firearms compared to those who resided in the central zone of the country (State of Mexico, Federal District, Morelos and Puebla) (Table 3)

Although there was information on the state and locality, it was impossible to perform any analysis because when the cases were stratified by year and cause, small groups were generated. 
Table 2. Homicide in children under five years of age according to weapon use mechanism for death. Mexico 1998 to 2017

\begin{tabular}{|c|c|c|c|c|c|c|}
\hline \multicolumn{7}{|l|}{ Homicide in girls } \\
\hline Mechanisms & 0 & 1 & 2 & 3 & 4 & Total \\
\hline Mechanısms & $\mathrm{n}(\%)$ & $\mathrm{n}(\%)$ & $\mathrm{n}(\%)$ & $\mathrm{n}(\%)$ & $\mathrm{n}(\%)$ & $\mathrm{n}(\%)$ \\
\hline Other means & $288(42.5)$ & $151(47.6)$ & $123(46.9)$ & $66(34.0)$ & $57(33.9)$ & $685(42.3)$ \\
\hline Hanging and strangulation & $157(23.2)$ & $25(7.9)$ & $14(5.3)$ & $24(12.4)$ & $16(9.5)$ & $236(14.6)$ \\
\hline Firearm & $36(5.3)$ & $35(11.0)$ & $41(15.6)$ & $49(25.3)$ & $38(22.6)$ & 199 (12.3) \\
\hline Negligence, abandonment and abuse & $113(16.7)$ & $28(8.8)$ & $17(6.5)$ & 15 (7.7) & $10(6.0)$ & $183(11.3)$ \\
\hline Drowning & $32(4.7)$ & $38(12.0)$ & $31(11.8)$ & $10(5.2)$ & $8(4.8)$ & $119(7.4)$ \\
\hline Sharp instrument & $31(4.6)$ & $16(5.0)$ & $18(6.9)$ & $20(10.3)$ & $24(14.3)$ & $109(6.7)$ \\
\hline Beatings, rape & $15(2.2)$ & $17(5.4)$ & $14(5.3)$ & $6(3.1)$ & $7(4.2)$ & $59(3.6)$ \\
\hline Corrosive substance & $3(0.4)$ & $5(1.6)$ & $4(1.5)$ & $3(1.5)$ & $8(4.8)$ & $23(1.4)$ \\
\hline Poisoning & $2(0.3)$ & $2(0.6)$ & 0 & $1(0.5)$ & 0 & $5(0.3)$ \\
\hline Total & $677(100)$ & $317(100)$ & $262(100)$ & $194(100)$ & $168(100)$ & $1618(100)$ \\
\hline \multicolumn{7}{|l|}{ Homicide in boys } \\
\hline Other means & $384(47.9)$ & $180(44.7)$ & 147 (41.1) & $74(32.7)$ & $81(35.2)$ & $866(42.9)$ \\
\hline Firearm & $38(4.7)$ & $67(16.6)$ & $71(19.8)$ & $65(28.8)$ & $83(36.1)$ & $324(16.0)$ \\
\hline Hanging and strangulation & $168(20.9)$ & $30(7.4)$ & $28(7.8)$ & $18(8)$ & $17(7.4)$ & 261 (12.9) \\
\hline Negligence, abandonment and abuse & $116(14.5)$ & $24(6.0)$ & $27(7.5)$ & $14(6.2)$ & $13(5.7)$ & $194(9.6)$ \\
\hline Drowning & $30(3.7)$ & $54(13.4)$ & $48(13.4)$ & $20(8.8)$ & $17(7.4)$ & $169(8.4)$ \\
\hline Sharp instrument & $49((6.1)$ & $18(4.5)$ & $22(6.1)$ & $20(8.8)$ & $13(5.7)$ & $122(6.0)$ \\
\hline Beatings, rape & $9(1.1)$ & $21(5.2)$ & $13(3.6)$ & $6(2.7)$ & $4(1.7)$ & $53(2.6)$ \\
\hline Corrosive substance & $5(0.6)$ & $2(0.5)$ & $2(0.6)$ & $4(1.8)$ & $2(0.9)$ & $15(0.7)$ \\
\hline Poisoning & $3(0.4)$ & 7 (1.7) & 0 & $5(2.2)$ & 0 & $15(0.7)$ \\
\hline Total & $802(100)$ & $403(100)$ & $358(100)$ & $226(100)$ & $230(100)$ & 2019 (100) \\
\hline
\end{tabular}

Source: Prepared from the databases of the National Health Information System (Sistema Nacional de Información en Salud - SINAIS, 1998-2017).

The data is presented as $\mathrm{n}(\%)$.

Table 3. Mechanisms of death by region, sex and age groups. Mexico. 1998 to 2017.

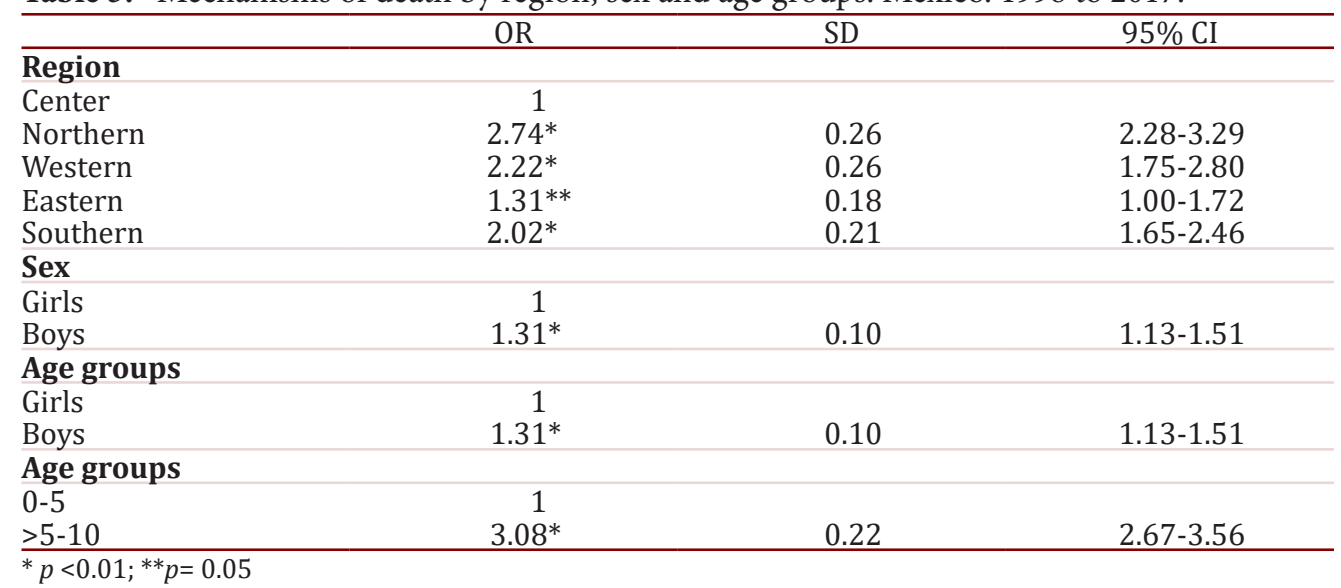

\section{Discussion}

The study shows that the mortality records for homicide in children between 0-10 years of age in Mexico had few changes over more than two decades. However, during some years of the study period, homicide rates in girls were almost equal to those in boys, and firearms followed by hangings and strangulation were the most common types of homicides in children.

In under one year, the information coincides with the results of a study in Turkey that characterized homicides perpetrated by mothers (filicide) to children under six years in which hands were used as a criminal tool; throwing their daughters from heights was the second most common method of filicide. In addition, it was identified that mothers used gauze, cloth or socks to kill their children ${ }^{15}$. 
The sex difference in mortality patterns differed from that reported in a previous study performed by other authors ${ }^{6}$. In that study, the risk of dying from homicide was almost three times higher for boys under five years than for girls, while in the present analysis, the differences were considerably smaller (close to $1: 1$ ). However, the findings coincide with those of another study, which reported a high percentage of deaths among children under one year in both sexes ${ }^{16}$; in that study, the most frequent mechanism were nonspecific, indicating that the violence continues to be used against the most vulnerable. In Taiwan, the analysis of a decade's data showed that children under five years of age were likely to be attacked with force, and suffocation was still the leading cause of death. Cranial and facial injuries were more prevalent in children under five years of age ${ }^{17}$.

In a comparison of the records of violent mortality in children 0-5 years and 5-10 years with those of another Latin American country, such as Colombia, over the last three years ${ }^{18}$, it was observed that the risk of dying due to homicide in general was slightly higher in Mexico compared to Colombia. For example, in Mexico, the homicide mortality rate in girls aged $0-5$ years was 1.25/100,000, while in Colombia, it was 1.01/100,000. The same was true for girls aged 5 - 10 years; the rate was slightly higher for Mexican girls $(0.57 / 100,000)$ than for Colombian girls $(0.48 / 100,000)$. For boys, the differences were smaller, so much so that for 5 - to 10 -yearolds, the risks of mortality due to homicide were similar for both countries $(0.70 / 100,000)$.

In Africa, a study of the mortality records from 38 medical-legal laboratories for children under 18 years found a higher rate of homicides in males, and this rate was highest among those older than five years ${ }^{19}$. The behavior differed by type and place of occurrence; for females, the highest percentage of events occurred within the nuclear family (18.9\%). The use of sharp objects was more frequent for males, while strangulation was more frequent among females; among children, weapons were a greater cause of death. Another finding corresponded to differences in the type of weapon used/mechanism for homicides; for children five years and older, homicides were linked to child abuse, while for girls, they were due to carelessness. The findings in Mexico were similar for the girls in terms of the place of occurrence and cause of death ${ }^{19}$.

It is important to mention that violence against children is increasingly being perpetrated in public spaces, where it is likely that there are witnesses to such violence who at a given moment could act to reduce the severity of the damage. However, the home is where violence is reproduced and where acts of violence affect the most vulnerable ${ }^{20}$, in this case, children 0-9 years; in which, differences by sex were evidenced, with homicides in girls occurring at home being higher. Thus, home as a safe environment should be a priority in the set of interventions to prevent violence against girls, targeting to strengthen parenting skills and address social norms, and seeking to reduce the incidence of various types of injuries ${ }^{21}$.

Evidence emphasizes that such violence is generated by someone close to the child or a relative ${ }^{22,23}$; in many cases, violence is perpetrated by the victim's parents themselves ${ }^{24}$. It is possible that the increase in mortality in some years of the study period (especially in 2009) was related to revenge among criminal gangs, linked to drug trafficking problems throughout the country, particularly in the Mexican Northern-Area. That situation might also be associated with the confronted war made by the Government of former President Calderón against drug trafficking carried out during his mandate, resulting in many thousands of deaths ${ }^{25,26}$.

This study provides evidence on violent mortality among minors in Mexico; however, the following issues are recognized as potential limitations, similarly to other results found by other authors ${ }^{27,28}$

Misclassification or underreporting of violent mechanism for death in children, given that the source of information was secondary records;

Measurement error due to missing information for age and sex, although this issue was corrected with the imputation methods identified in the methodology; 
The high proportion of nonspecific mechanisms for death in both children, which underestimates the proportion of deaths from known mechanism; i.e., the magnitude of incidences of beatings, hanging, firearm violence, among other mechanisms, may be underestimated by not having complete information that could guide more specific measures to control and prevent violent acts;

The impossibility of establishing the relationship between the victim (the minor) and the perpetrator responsible for his or her death, which makes it necessary to continue insisting to the responsible authorities that, in the specific case of homicides, the death certificate should include the option of recording the relationship between the victim and the perpetrator. This would allow for the development of better policy proposals to prevent violent mortality.

As has been described in other Latin American contexts, the lack of specificity of violent death mechanisms should motivate the improved investigation and recording of these events in a way that leads to the generation of effective proposals to combat them ${ }^{29-31}$. In this context, the observatories of violence, an intersectoral and inter-institutional coordination strategy, could contribute to the generation of reliable information, the product of the validation of data and information among the competent entities on the subject ${ }^{32,33}$.

Furthermore, serious and focused efforts are necessary to document the general situation of children under five years, who comprise the population most vulnerable due to violence. Several aspects that could be considered: mental health problems or dysfunction in parents or caregivers of children under ten years of age, and the presumptive signs and/or symptoms of situations of violence that can be identified by health professionals during medical consultations ${ }^{15,34}$. We believe that these issues need to be followed in future studies where we could identify the possible correlation among homicides in children, hospitalization due to intentional injuries and complaints of physical abuse in this population.

\section{Conclusions}

The present study identified that the trend in mortality for these population groups remained similar throughout the study period studied: on average, a child under five years of age was murdered every two days, while for those aged five and above, one death occurs every five days. This could reflect the limited efforts to combat and eradicate this form of child mortality in the country.

Evidence beyond the statistical data was presented in hopes of drawing attention to the urgent need for committed efforts from the sectors empowered to secure the fundamental right to life for boys and girls in Mexico to search for proven strategies such as those suggested in the INSPIRE handbook, an initiative of several international organizations and non-governmental organizations; such strategies establish that education and attitudes towards life, the response and support of institutions responsible for access to justice, and the establishment of norms and values that promote the participation of adolescents and young people are effective measures to end all forms of violence against children.

Other future studies could develop to identify some correlations among homicides in children, hospitalization due to intentional injuries, and complaints of physical abuse in this population. Moreover, observatory programs could be used to improve the quality of administrative records for decision-making. 


\section{References}

1. UNICEF. Convención sobre los derechos del niño. Madrid: UNICEF; 2006.

2. Riquer MFM, Castro R. Estudio nacional sobre las fuentes, orígenes y factores que producen y reproducen la violencia contra las mujeres. Presentación y síntesis de resultados. México: Comisión Nacional para prevenir y erradicar la violencia; 2012. Available from: http://www.conavim.gob.mx/work/models/CONAVIM/ Resource/103/1/images/1PresentacionResultadosEstudioNacionalsobrelasFuentesOrigenes.pdf.

3. Irwin LG, Siddiqi A, Hertzman C. Desarrollo de la primera infancia: un potente ecualizador. Informe final para la Comisión sobre los Determinantes Sociales de la Salud. OMS; 2007. Available from: https://www.who.int/ socialdeterminants/publications/early_child_dev_ecdkn_es.pdf

4. Peden M, Oyegbite K, Ozanne-Smith J, Hyder AA, Branche C, Fazlur RAKM, et al. Violence and injury prevention. World report on child injury prevention. World Health Organization; UNICEF; 2008. Available from: https://www.who.int/violence_injury_prevention/child/injury/world_report/en/

5. Organización Panamericana de la Salud, Oficina Regional para las Américas de la OMS. Informe mundial sobre la violencia y la salud: resumen. Washington, D.C.; 2002. Available from: http://apps.who.int/iris/bitstream/ handle/10665/43431/9275324220_spa.pdf?sequence=1

6. Híjar M, Tapia R, Rascón RA. Mortalidad por homicidio en niños en Me'xico,1979-1990. Salud Pública Méx. 1994; 36(5): 529-537.

7. Sattin R, Corso P. Chapter 1. The epidemiology and costs of unintentional and violent injuries. En: Doll L, Bonzo S, Sleet D, Mercy J. Handbook of injury and violence prevention. Springer-Verlag: US; 2007. DOI:10.1007/b136518.

8. Arcos E, Uarac M, Molina I. Impacto de la violencia domestica en la salud infantil. Med Chil. 2003; 131: 14541462. doi: $10.4067 / S 0034-98872003001200014$

9. Organización Mundial de la Salud. Manual INSPIRE: Medidas destinadas a implementar las siete estrategias para poner fin a la violencia contra los niños Ginebra: Organización Mundial de la Salud; 2019. Available from: https://apps.who.int/iris/bitstream/handle/10665/311034/9789243514093-spa.pdf?ua=1

10. World Health Organization. International statistical classification of diseases and related health problems. 10th revision, edition 2010. WHO; 2011 Available from: https://www.who.int/classifications/icd//CD10Volume2_en_2010.pdf

11. Naghavi M, Makela S, Foreman K, O’Brien J, Pourmalek F, Lozano R. Algorithms for enhancing public health utility of national causes of death data. Population Health Metrics. 2010; 8(9): 1-14. Doi: 10.1186/1478-7954-8-9.

12. Bhalla K, Shahraz S, Naghavi M, Lozano R, Murray C. Estimating the distribution of external causes in hospital data from injury diagnosis. Accid Anal Prev. 2008; 40(6): 1822-1829. Doi: 10.1016/j.aap.2008.07.002

13. Organización Panamericana de Salud. Situación de salud en las Américas: indicadores básicos 2009. OPS/ HSD/HA/09.01. OPS; 2009. Available from: https://www.paho.org/clap/index.php?option=com_docman\&view=document\&layout=default\&alias=125-situacion-de-salud-en-las-americas-indicadores-basicos-2009\&category_slug=otros-documentos\&ltemid=219\&lang=es.

14. StataCorp. Stata Statistical Software: Release 13. College Station, TX: StataCorp LP; 2013.

15. Eke S, Basoglu S, Taktak S, Oral G. Analysis of the maternal filicide in terms of forensic medicine in Turkey: a clinical research. Noro Psikiyatr Ars. 2015; 52(1): 78-82. Doi: 10.5152/npa.2015.7075. 
16. Gutiérrez-Trujillo G, Fernández-Cantón S, Viguri-Uribe R. Homicidios en menores de 15 años de edad, México 2000-2010. Informe preliminar. Bol Med Hosp Infant Mex. 2011: 68; 253-258.

17. Hwa H-L, Pan C-H, Shu G-M, Chang C-H, Lee T-T, Lee JC-I. Child homicide victims in forensic autopsy in Taiwan: A 10-year retrospective study. Forensic Sci Int. 2015; 257: 413-419. doi: 10.1016/j.forsciint.2015.10.020.

18. De la hoz BGA. Comportamiento del Homicidio, Colombia 2013. Instituto Nacional de Medicina Legal y Ciencias Forenses; 2013. Available from: https://www.medicinalegal.gov.co/documents/20143/49517/Homicidio.pdf

19. Mathews S, Naeemah A, Jewkes R, Martin L, Lombard C. The epidemiology of child homicides in South Africa. Bull World Health Organ. 2013; 91(8): 562-68. Doi: 10.2471/BLT.12.117036.

20. Ballestín G, Corbellas C, Blasco A. Capítulo 5. El duelo en la perdida de un hijo. En: Camps C, Sánchez P. Duelo en oncología. Madrid: SEOM; 2006. p:85-101. Available from: https://seom.org/seomcms/images/stories/ recursos/sociosyprofs/documentacion/manuales/duelo/duelo09.pdf.

21. United Nations Office on Drugs and Crime UNODC. Global study on homicide 2019. Killing of children and young adults. Vienna: UNODC; 2009. Available from: https://www.unodc.org/documents/data-and-analysis/gsh/ Booklet_6new.pdf.

22. Brown J, Cohen P, Johnson J, Salszinger S. A longitudinal analysis of risk factors for child maltreatment: findings of a 17-year prospective study of officially recorded and selft-reported child abuse and neglect. Child Abuse Negl. 1998; 22(11): 1065-1078. Doi: 10.1016/s0145-2134(98)00087-8.

23. Fernández CG, Perea CJ. Maltrato infantil físico en pacientes diagnosticados en el hospital pediátrico Juan M. Márquez, 1996-1998. Rev Cubana Pediatr. 2004; 76(4).

24. Vargas-Sanabria M. Muertes por agresión infantil en Costa Rica entre los años 2003 y 2011. Med Leg Costa Rica. 2012; 29(2): 7-18.

25. Hijar MMC, Rodríguez JM, Hernández AMA, Campuzano RJC. Capitulo III Tras la evidencia de la violencia contra las mujeres: un análisis de los homicidios. En: CONAVIM. Estudio nacional sobre las fuentes, orígenes y factores que producen y reproducen la violencia contra las mujeres. Tomo I, Volumen I. México; 2012. pp 134-307. Available from http://www.conavim.gob.mx/work/models/CONAVIM/Resource/103/1/images/EstudiosNacionalesTomolVolumenl.pdf.

26. Rodríguez JMR, Campuzano JC, Medina MH, Solorzano L, Chaparro PE. Comparing the patterns and trends of homicide mortality in mexico and colombia from 2000 to 2015 (differences and similarities). Arch Med. 2018; 10(6):1-8. Doi: 10.21767/1989-5216.1000292.

27. Comstock GW, Markush RE. Further comments on problems in death certification. Am J Epidemiol. 1986; 124(2): 180-1. Doi: 10.1093/oxfordjournals.aje.a114376

28. Celis dIRAJ, Valdez LM, Armas J, Gómez-Lomelí Z. El peatón lesionado en accidentes de tráfico de vehículo de motor: Mortalidad en México, 1985-1996. Gac Méd Mex. 1999; 135(3):353-358.

29. Cámara de Comercio de Bogotá. Protocolo de Bogotá sobre calidad de datos de homicidio en América Latina y el Caribe. Bogotá, Colombia: Cámara de Comercio de Bogotá; 2015. Cited: 12 August 2019. Available from: https://www.ccb.org.co/Sala-de-prensa/Noticias-CCB/2015/Noviembre-2015/Protocolo-de-Bogota-sobre-calidad-de-los-datos-de-homicidios-en-America-Latina-y-el-Caribe 
30. Srur J, Dammert L, Gutiérrez MI, Martin G, Paternain R, Peña N. ¿Qué observan los que observan el delito? Pasado, presente y futuro de los observatorios de crimen y violencia de América Latina y el Caribe. Banco Interamericano de Desarrollo. Washington; 2014. Available from: https://publications.iadb.org/publications/spanish/document/\%C2\%BFQu\%C3\%A9-observan-los-que-observan-el-delito-Pasado-presente-y-futuro-de-los-observatorios-del-crimen-y-la-violencia-en-Am\%C3\%A9rica-Latina-y-el-Caribe.pdf

31. Meneses R, Quintana M. Homicidios e investigación criminal en México. Perfiles Latinoamericanos 2016; 48: 297-318.

32. Franco M, Serrano A. Observatorios del delito en Colombia: funciones y propósitos. Rev Crim. 2009; 51(1): 193-207.

33. Fandiño-Losada A, Guerrero-Velasco R, Mena-Muñoz J, Gutiérrez-Martínez M. efecto del control del crimen organizado sobre la violencia homicida en Cali (Colombia). Rev CIDOB d'Afers Internacionals. 2017: 115; 159-178. Doi: 10.24241/rcai.2017.116.2.159.

34. Agius $\mathrm{M}$, Orr M, Osborne $\mathrm{D}$. The child as the presenting symptom, and what happens when things go wrong?. Psychiatria Danubina. 2009; 21(1): 137-141. 